\title{
HUKUM KODRAT DAN HUKUM POSITIF DALAM MEWUJUDKAN PEMILIHAN UMUM KEPALA DAERAH SERENTAK 2020 YANG BERINTEGRITAS
}

\author{
Jeremia Alexander Wewo \\ Fakultas Hukum Universitas Kristen Artha Wacana \\ Kupang-Nusa Tenggara Timur, Indonesia \\ Email: jeremiawewo92@gmail.com
}

\begin{abstract}
Abstrak
Pemilihan Umum Presiden dan Anggota Legislatif Tahun 2019 menjadi pengalaman dalam tulisan ini yang bertujuan untuk menemukan cara dalam mewujudkan Pemilihan Umum Kepala Daerah Serentak 2020 yang berintegritas. Permasalahan yang diangkat dalam tulisan ini adalah pandangan hukum kodrat dan hukum positif dalam mewujudkan pemilihan umum kepala daerah serentak 2020 yang berintegritas. Metode penelitian yang digunakan adalah metode penelitian hukum normatif empiris. Terdapat 2 (dua) grand theory yang digunakan sebagai pisau analisis yakni hukum kodrat dan hukum positif. Hasil pembahasan menunjukan bahwa penerapan hukum kodrat dan hukum positif dalam mewujudkan Pemilihan Umum Kepala Daerah yang berintegritas harus dilihat dari 2 (dua) aspek yakni aspek hukum dan aspek manusia. Kedua aspek ini harus membentuk satu kesatuan dan fungsi yang mengedepankan prinsip hukum kodrat dan akal budi agar mampu berjalan dan seiring dalam setiap konstelasi Pemilihan Umum. Saran yang diberikan dalam tulisan ini ialah titik persinggungan pokok antara hukum kodrat dan hukum positif yakni moral harus terus dimanifestasikan dalam kehidupan manusia terutama dalam setiap proses Pemilihan Umum.
\end{abstract}

\section{Kata Kunci: Hukum Kodrat; Hukum Positif; Pemilihan Umum.}

\begin{abstract}
The President 2019 and Legislative Members General Election is an experience in this paper that aims to find a way to realize the simultaneous Regional Election of $2020 \mathrm{Heads}$ with integrity. The problem raised in this paper is the view of natural law and positive law in realizing regional elections simultaneously with 2020 with integrity. The research method used is empirical normative legal research methods. There are 2 (two) grand theories that are used as analysis blades namely natural law and positive law. The results of the discussion showed that the application of natural law and positive law in realizing the Election of Regional Heads with integrity must be seen from 2 (two) aspects namely legal aspects and human aspects. These two aspects must form a unity and function that prioritizes the principles of natural law and reason to be able to go hand in hand and in each constellation of the General Election. The advice given in this paper is the main point of contact between natural law and positive law, which is that morality must continue to be manifested in human life, especially in every General Election process.
\end{abstract}

Keywords: General Election; Natural Law; Positive Law.

\section{A. PENDAHULUAN}

Negara Indonesia menganut paham demokrasi dan nomokrasi. Landasan yuridis sebagai negara demokrasi tercantum dalam Pasal 1 ayat (2) Undang-Undang Dasar Negara Republik Indonesia Tahun 1945 yang berbunyi "kedaulatan berada di tangan rakyat dan dilaksanakan menurut Undang-Undang Dasar". 'Berpijak pada landasan konstitusi menunjukkan, bahwa Indonesia menganut paham kedaulatan rakyat yang merupakan kekuatan istimewa dan

${ }^{1}$ Bambang Satriya. (2017). "Urgensi Integritas Penyelenggara Pemilihan Umum dalam Menegakkan Kedaulatan Rakyat". Jurnal Etika dan Pemilu, 3(1):10-21. 
fundamentalnya demokrasi. Demokrasi yang sering diidentikan dengan jargon "pemerintahan dari rakyat, oleh rakyat, dan untuk rakyat, menunjukkan kalau kesejatian demokrasi adalah kedaulatan rakyat. Adapun paham nomokrasi dapat dibuktikan dengan merujuk ketentuan Pasal 1 ayat (3) Undang-Undang Dasar Negara Republik Indonesia Tahun 1945 yang menegaskan "negara Indonesia adalah negara hukum". Garis konstitusi inilah sebagai dasar paham kedaulatan hukum yang pada pokoknya menganut prinsip supremasi hukum. Artinya segala aspek kehidupan berbangsa dan bernegara harus merujuk pada hukum yang berlaku. ${ }^{2}$

Prinsip fundamental dalam berdemokrasi yang diterapkan di banyak negara adalah Pemilihan Umum, dan bahkan Pemilihan Umum merupakan instrumen demokrasi yang hampir semua negara di dunia ini, memilih menggunakan mekanisme Pemilihan Umum sebagai sarana pelaksanaan kedaulatan rakyat.

Pemilihan Umum merupakan mandat dari konstitusi yang wajib dilaksanakan oleh pemerintah, dalam hal ini memastikan dan melindungi hak-hak politik rakyat tersalur dalam proses Pemilihan Umum. Sependapat dengan hal ini, Kusnardi dan Harmaili Ibrahim, mengatakan bahwa Pemilihan Umum adalah salah satu hak asasi warga negara yang sangat prinsipil, karena dalam pelaksanaan hak asasi adalah suatu keharusan pemerintah untuk melaksanakan Pemilihan Umum. Oleh karena itu Pemilihan Umum adalah suatu syarat mutlak bagi negara Indonesia. ${ }^{3}$

Di Indonesia, terdapat tiga jenis Pemilihan Umum yaitu Pemilihan Umum Presiden dan Wakil Presiden, Anggota Legislatif dan Kepala Daerah dan Wakil Kepala Daerah. Pemilihan Umum yang dilaksanakan di Indonesia menganut asas LuberJurdil, yaitu : ${ }^{4}$

a. Langsung, berarti pemilih diharuskan memberikan suaranya secara langsung dan tidak boleh diwakilkan.

b. Umum, Pemilihan Umum dapat diikuti seluruh warga negara yang sudah memiliki hak menggunakan suara.

c. Bebas, pemilih diharuskan memberikan suaranya tanpa ada paksaan dari pihak manapun.

d. Rahasia, suara yang diberikan oleh pemilih bersifat rahasia yang hanya diketahui oleh pemilih itu sendiri.

e. Jujur, Pemilihan Umum harus dilaksanakan sesuai dengan aturan untuk memastikan bahwa setiap warga negara memiliki hak dapat memilih sesuai dengan kehendaknya dan setiap suara pemilih memiliki nilai yang sama untuk menentukan wakil rakyat yang akan terpilih.

f. Adil, perlakuan yang sama terhadap peserta Pemilihan Umum dan pemilih, tanpa ada pengistimewaan atau diskriminasi terhadap peserta atau pemilih tertentu. Asas jujur dan adil mengikat tidak hanya peserta Pemilihan Umum, tetapi juga penyelenggara Pemilihan Umum.

Untuk menjamin terselenggaranya Pemilihan Umum, peran rakyat tidak cukup, melainkan peran penyelenggara Pemilihan Umum yang bersama-sama dengan rakyat untuk menciptakan Pemilihan Umum yang sesuai dengan cita-cita rakyat Indonesia.

Menyambut Pemilihan Umum Kepala Daerah Serentak 270 daerah ${ }^{5}$ di Indonesia yang akan berlangsung tahun 2020, masih terdapat beberapa pekerjaan rumah untuk pemerintah dalam mewujudkan Pemilihan Umum Kepala Daerah Serentak 2020 yang berintegritas. Adapun

${ }^{2}$ Jeremia Alexander Wewo. Kotan Y. Stefanus. and Umbu Lili Pekuwali. (2018). Code Of Ethics Urgency In The Implementation Of General Election In Indonesia. Jurnal Dinamika Hukum, Faculty Of Law Universitas Jenderal Soedirman, 18 (2): 194-199.

${ }^{3}$ Moh.Kusnardi dan Harmaili Ibrahim. (1993). Pengantar Hukum Tata Negara. Jakarta:Sinar Bakti, hlm.329.

${ }^{4}$ Wikipedia Indonesia, Pemilihan Umum di Indonesia, diakses pada Tanggal 29 Oktober 2019 Jam 19.30 Wita

${ }^{5}$ Tersedia dalam https://news.detik.com/berita/d-4596501/ini-270-daerah-yang-gelar-pilkada-serentak-2020 diakses pada Tanggal 29 Oktober Jam 20.25 Wita 
persoalan-persoalan atau permasalahan-permasalahan yang terjadi pada Pemilihan Umum Presiden dan Wakil Presiden serta Pemilihan Umum Anggota Legislatif 2019 yaitu: ${ }^{6}$

1. Penetapan Daftar Pemilih Tetap (DPT). Warga yang telah memenuhi syarat sebagai pemilih belum dimasukkan dalam Daftar Pemilih Tetap.

2. Masakampanye,pesertaPemilihanUmum2019dilarangberkampanyedilembagapendidikan, pemerintahan, dan tempat ibadah, seperti tercantum dalam Undang-Undang nomor 7 tahun 2017 tentang Pemilihan Umum. Namun, dalam ajang Pemilihan Umum Presiden dan Wakil Presiden 2019, kandidat dari kubu nomor urut 01 Joko Widodo-Ma'ruf Amin dan nomor urut 02 Prabowo Subianto-Sandiaga Uno, sempat melakukan safari ke pesantren.

3. Perusakan Alat Peraga Kampanye (APK). Contoh konkretnya ialah Partai Demokrat dan Partai Solidaritas Indonesia telah melapor ke kepolisian karena Alat Peraga Kampanye yang terpasang di ruang publik telah dirusak.

4. Material kotak suara dipermasalahkan (kotak suara berbahan karton duplex). Hal ini telah diklaim oleh Komisi Pemilihan Umumkarenatelah sesuai Peraturan Komisi Pemilihan Umum (PKPU) Nomor 15 Tahun 2018 tentang Norma, Standar, Prosedur Kebutuhan Pengadaan dan Pendistribusian Perlengkapan Penyelenggaraan Pemilihan Umum.

Selain 4 (empat) masalah tersebut menurut penulis terdapat lagi beberapa masalah krusial yakni masalah hoax yang menjatuhkan elektabilitas ${ }^{7}$ salah satu pasangan calon Presiden dan Wakil Presiden dan masalah politik uang. Hal yang terakhir disebutkan sepertinya telah menjadi roh dalam setiap proses Pemilihan Umum. Contoh konkretnya pada tahapan pra Pemilihan Umum tentu ada sosialisasi-sosialisasi dari para Calon Anggota Legislatif berbagai daerah. Hal ini menurut penulis, merupakan momentum untuk para Calon Anggota Legislatif untuk menyampaikan visi misi tetapi hal ini telah luntur karena dalam setiap sosialisasi selalu saja berbicara tentang nominal uang yang akan diberikan kepada warga untuk memilih salah satu Calon Anggota Legislatif pada saat proses pemilihan. Selain itu, bukan hanya Calon Anggota Legislatif yang membicarakan tentang nominal uang tetapi warga sebagai pemilih juga turut serta berbicara mengenai nominal uang dan menentukan jumlah uang yang harus diberikan oleh salah satu calon Anggota Legislatif kepada warga pada saat proses pemilihan.

Mengacu pada permasalahan-permasalahan yang terjadi pada saat Pemilihan Umum 2019, penulis berpendapat bahwa apabila persolan yang sama terjadi lagi pada saat Pemilihan Umum Kepala Daerah Serentak 2020 tentu akan menghancurkan sendi-sendi demokrasi yang berujung pada hilangnya integritas suatu Pemilihan Umum. Untuk hal itu, permasalahan yang diangkat oleh penulis ialah bagaimana penerapan hukum kodrat dan hukum positif dalam mewujudkan Pemilihan Umum Kepala Daerah Serentak yang berintegritas.

\section{B. METODE PENELITIAN}

Di dalam penelitian hukum terdapat beberapa pendekatan sesuai dengan karakter dan jenis penelitian. ${ }^{8}$ Dengan pendekatan tersebut, peneliti akan mendapatkan informasi dari berbagai aspek mengenai issu yang sedang dicoba untuk dicari jawabannya. Guna menjawab permasalahan dalam penelitian ini, adapun pendekatan-pendekatan yang digunakan diantaranya adalah: ${ }^{9}$

(1)Pendekatan peraturan perundang-undangan (statute approach) yakni pendekatan yang dilakukan dengan menelaah beberapa Peraturan Perundang undangan tertentu dan/atau

${ }^{6}$ Tersedia dalam https://beritagar.id/artikel/berita/masalah-dan-potensi-masalah-menjelang-pemilu-2019 diakses pada tanggal 29 Oktober 2019 Jam 20.45 Wita

${ }^{7}$ Menurut Kamus Besar Bahasa Indonesia, Elektabilitas ialah kemampuan atau kecakapakan untuk dipilih menduduki suatu jabatan atau pemerintahan

${ }^{8}$ Peter Mahmud Marzuki. (2005). Penelitian Hukum. Jakarta: Kencana. hlm 93.

${ }^{9} I b i d .$, hlm 95.

252 Jeremia A. Wewo | Hukum Kodrat dan Hukum Positif.... 
regulasi yang bersangkut paut dengan issu hukum yang menjadi obyek diteliti dan sejalan dengan fenomena empiris berkenaan dengan penerapan hukum positif.

(2)Pendekatan konseptual (conceptual approach) yaitu pendekatan yang mengkaji dari aspek kepustakaan ilmu hukum berkaitan dengan teori, asas, doktrin maupun konsep dari pandangan para ahli yang berkembang mempengaruhi referensi hukum, terutama yang berkenaan dengan permasalahan yang di bahas dalam penelitian ini.

(3)Pendekatan sosiologis (sociological approach), yaitu pendekatan untuk mengamati dan menghimpun bahan dan informasi berkenaan dengan sikap tindak/perilaku dari subyek yang mempunyai hubungan hukum dengan obyek yang diatur dalam penerapan hukum yang berlaku.

\section{PEMBAHASAN}

\section{Keberadaan Hukum Kodrat pada Keberlakuan Hukum Positif dalam Mewujudkan} Pemilihan Umum Kepala Daerah Serentak yang berintegritas

Para teoretisi Hukum Kodrat sering menyatakan bahwa hukum kodrat berfungsi sebagai standar regulatif atau standar pengaturan hukum positif. Hubungan antara hukum kodrat dan hukum positif biasanya dirumuskan dalam term-term ${ }^{10}$ hak. Hak adalah sesuatu yang diberikan kepada orang lain atas dasar asas kesamaan. Sesuatu dapat menjadi hak seseorang melalui 2 (dua) cara yakni, pertama, sesuatu dapat menjadi hak seseorang melalui kodratnya. Hak ini disebut hak kodrat. Hak kodrat sebagaimana diatur oleh hukum kodrat memiliki akarnya didalam Hak Ilahi (Hukum Abadi). Kedua, sesuatu dapat menjadi hak seseorang melalui perjanjian atau persetujuan dengan orang lain, baik persetujuan antar orang individual atau maupun persetujuan publik. Hak yang kedua ini disebut hak positif dan diatur dalam hukum positif."

Jika dalam menerapkan hukum, para legislator atau para hakim gagal untuk membuat keputusan yang dapat mendatangkan kebaikan umum, bertindak melampaui batas kewenangannya, atau memberi beban pada subjek hukum secara tidak proporsional, maka fakta ini dapat dijadikan dasar bagi hukum kodrat untuk mengkritik hukum positif dan keputusankeputusan yudisial. ${ }^{12}$

Menurut penulis, keterkaitan hukum positif pada hukum kodrat ini adalah perlu dan merupakan syarat legitimasi keberlakukan hukum positif. Lebih lanjut menurut penulis, hukum positif menerapkan prinsip umum hukum kodrat pada ruang lingkup khusus sehingga hal ini secara khusus mempengaruhi perilaku subjek hukum positif, baik dengan cara menarik kesimpulan dari prinsip umum maupun dengan cara membentuk aturan-aturan tertentu yang diilhami oleh prinsip umum tersebut. Pada konteks ini, hukum kodrat akan menuntut subjek hukum berperilaku secara berbeda-beda, disesuaikan dengan hukum positif yang berlaku. Pengkhususan atas hak-hak yang berada dibawah hukum kodrat itu bergantung pada hukum positif, atau dengan kata lain merupakan sarana untuk menerapkan asas-asas umum hukum kodrat dalam kehidupan nyata manusia didalam masyarakat.

Apabila dihubungkan dengan pembahasan pada subbab ini yang berkaitan dengan keberadaan hukum kodrat pada keberlakukan hukum positif dalam mewujudkan Pemilihan Umum yang berintegritas. Dalam konteks ini, yang menjadi bahan kritisi oleh penulis berkaitan dengan keberadaan suatu aturan atau regulasi dari Pemilihan Umum Kepala Daerah, karena regulasi atau aturan merupakan dasar dari pelaksanaan suatu proses Pemilihan Umum Kepala

\footnotetext{
${ }^{10}$ Term menurut Kamus Besar Bahasa Indonesia ialah istilah, kata atau frasa yang menjadi subjek atau predikat dari sebuah proposisi

${ }^{11}$ E Sumaryono. (2002). Etika dan Hukum. Depok:Kanisius, hlm.17

${ }^{12} \mathrm{Ibid}$,
} 
Daerah. Berbicara tentang regulasi tentu sebagaimana diketahui bahwa dalam Pemilihan Umum Kepala Daerah menggunakan regulasi Undang-Undang Nomor 10 Tahun 2016 Selain mengkritisi aspek regulasi dalam hal ini penulis mengkritisi aspek manusia.

Lebih lanjut, kedudukan Undang-Undang Nomor 10 Tahun 2016 merupakan suatu bentuk keberadaan hukum positif dalam konstelasi Pemilihan Umum Kepala Daerah. Setelah itu, yang menjadi pertanyaan mendasar dalam tulisan ini ialah apakah Undang-Undang Nomor 10 Tahun 2016 Tentang Pemilihan Umum Kepala Daerah telah mengakomodir kepentingan rakyat guna mewujudkan Pemilihan Umum Kepala Daerah Serentak yang berintegritas.

Permasalahan-permasalahan yang sebelumnya telah penulis rangkai pada uraian pendahuluan sebenarnya memberikan justifikasi kepada penulis bahwa aturan hukum Pemilihan Umum itu seakan-akan tidak ada gunanya apabila masih saja terjadi penyimpangan-penyimpangan yang bersifat ke-Pemiluan. Dalam hal ini, penulis meminjam istilah atau pendapat Sajipto Raharjo yang identik dengan Konsep Hukum Progresif yang mengatakan atau menjelaskan secara eksplisit bahwa Hukum itu diciptakan untuk Manusia.

Lebih lanjut, dengan filosofi tersebut maka manusia menjadi penentu dan titik orientasi hukum. Hukum bertugas melayani manusia bukan sebaliknya, oleh karena itu, hukum itu bukan merupakan institusi yang lepas dari kepentingan manusia. Mutu hukum, ditentukan oleh kemampuannya mengabdi pada kesejahteraan manusia. Ini menyebabkan hukum progresif menganut ideologi hukum yang pro keadilan dan hukum yang pro rakyat.

Karena hukum progresif menempatkan kepentingan dan kebutuhan manusia/rakyat sebagai titik orientasinya, maka ia harus memiliki kepekaan pada persoalan-persoalan yang timbul dalam hubungan-hubungan manusia. Salah satu persoalan krusial dalam hubungan-hubungan sosial adalah keterbelengguan manusia dalam struktur-struktur yang menindas, baik politik, ekonomi, maupun sosial budaya. Dalam konteks, keterbelengguan tersebut, hukum progresif harus tampil sebagai institusi yang emansipatoris (membebaskan).

Sama halnya dengan Sajipto Raharjo, John Austin dalam Teori Positivisme Hukum Positif Analitis juga mengungkapkan bahwa seyogianya Hukum yang dibuat baik oleh Tuhan maupun oleh manusia sesungguhnya untuk manusia. Lebih lanjut, dalam hukum yang baik harus memuat perintah (command), sanksi (sanction), kewajiban (duty), dan kedaulatan (sovereignty).

Dari kedua konsep hukum untuk manusia sesungguhnya penulis berpendapat bahwa kalau memang hukum diciptakan atau dibentuk untuk manusia seharusnya manusia tidak perlu melakukan perbuatan atau perilaku menyimpang dan tidak taat pada hukum.

Lebih lanjut, dalam pembahasan ini penulis sejujurnya tidak dapat mengatakan bahwa suatu aturan hukum Pemilihan Umum yang diturunkan dari Konstitusi yakni Undang-Undang Nomor 10 Tahun 2016 belum sepenuhnya baik. Tetapi fakta atau penyimpangan-penyimpangan yang terjadi seakan-akan menjadi tolok ukur untuk memberikan justifikasi tentang Undang-Undang Nomor 10 Tahun 2016.

Pada kesempatan yang kedua, penulis melakukan pembedahan pada aspek manusia dalam Pemilihan Umum. Proses Pemilihan Umum tidak dapat terlepas dari keberadaan atau eksistensi dari. Kehadiran manusia disini sebagai rakyat yang memilih pemimpin pada saat Proses Pemilihan Umum serta Penyelenggara Pemilihan Umum. Berbicara tentang manusia, penulis mengutip pendapatnya Lawrence Friedman yang berbicara tentang sistem hukum dihuni oleh 3 (tiga) unsur yakni: ${ }^{13}$

1. Struktur hukum

2. Substansi hukum

3. Budaya hukum

${ }^{13}$ Muhammad Erwin. (2012). Filsafat Hukum; Refleksi Kritis Terhadap Hukum. Jakarta: Raja Grafindo Persada, hlm.107

254 Jeremia A. Wewo | Hukum Kodrat dan Hukum Positif.... 
Struktur merupakan bagian yang memberi bentuk dan batasan terhadap keseluruhan. Bagian yang memberi bentuk tersebut adalah institusi-institusi penegakan hukum. Substansi adalah aturan, norma, dan perilaku nyata manusia yang berada dalam sistem itu. Substansi bukan hanya aturan yang ada dalam undang-undang, namun mencakup pula hukum yang hidup (living law). Selanjutnya, budaya hukum merupakan suasana pikiran sosial dan kekuatan sosial yang menentukan bagaimana hukum digunakan, dihindari atau disalahgunakan. ${ }^{14}$

Berdasarkan pendapat Lawrence Friedman, dapat dikatakan bahwa yang menjadi struktur dalam Pemilihan Umum yakni Komisi Pemilihan Umum, Badan Pengawas Pemilihan Umum, dan Dewan Kehormatan Penyelenggara Pemilihan Umum. Lebih lanjut, yang menjadi substansi ialah Undang-undang atau aturan yang berkaitan dengan Pemilihan Umum serta perilaku manusia dalam Pemilihan Umum serta yang menyangkut budaya ialah kebiasaan atau perbuatan yang dilakukan atau disalahgunakan pada saat Pemilihan Umum.

Komposisi sistem Pemilihan Umum ini terus berubah mengikuti perkembangan masyarakat. Hal inilah yang selalu menjadi pekerjaan rumah bagi bangsa Indonesia, dengan berubahnya perkembangan masyarakat tentu keberadaan hukum atau aturan Hukum Pemilihan Umum. Konsep ini akan terus mengalami pertumbuhan dan menguat pada bangsa Indonesia pada saat Pemilihan Umum. Perubahan-perubahan Undang-undang Pemilihan Umum telah memberikan pandangan bagi penulis bahwa sesungguhnya Undang-undang Pemilihan Umum sebelumnya belum mampu mengakomodir kepentingan rakyat.

Pada pembahasan yang kedua tentang manusia, sesungguhnya merupakan suatu perbandingan tentang keberadaan hukum dan manusia dalam proses Pemilihan Umum. Sebagai bentuk pemikiran, apabila hukum Pemilihan Umum itu telah ada maka harus dijalankan dan ditaati oleh manusia. Apabila manusia tidak menaati dan menjalankan Undang-undang Pemilihan Umum dengan baik maka penyimpangan-penyimpang yang terjadi Pra-Pemilihan Umum, Proses Pemungutan Suara, Pasca-Pemilihan Umum akan terus terjadi dalam setiap konstelasi Pemilihan Umum. Lebih lanjut, dalam hal ini penulis mengatakan bahwa balance antara hukum dan manusia diperlukan dalam setiap proses atau tahapan Pemilihan Umum.

Untuk mengakomodir pertentangan atau perdebatan antara hukum dan manusia pada saat proses Pemilihan Umum, dalam hal ini penulis menawarkan konsep pemikiran baru menggunakan hukum kodrat yang tergolong lama bagi pemikir filsafat hukum.

Konfigurasi hukum menurut hukum kodrat ialah hukum yang berlaku bukan secara dipaksakan oleh kekuasaan manusia, namun mengikat kewajiban manusia untuk menaatinya. Hukum kodrat memerintahkan manusia untuk cinta kebaikan dan menjauhi kejahatan dan bila perlu dihayati melalui hati nurani manusia. Dalam konstelasi Pemilihan Umum, hukum kodrat mempunyai makna terhadap hukum positif yang dijelaskan melalui fungsi sebagai berikut:

1. Hukum kodrat menjadi dasar pengaturan hukum positif

Proses pembentukan dan pengundangan suatu aturan hukum Pemilihan Umum memerlukan keberadaan hukum kodrat. Norma-norma kebaikan yang tertuang dalam hukum kodrat harus termuatdalampengaturanUndang-undangPemilihanUmum.AturanhukumPemilihanUmum dapat dikatakan seimbang dan ditaati apabila manusia menaati hukum dan tidak melakukan perbuatan atau perilaku menyimpang serta hukum tersebut harus mampu mengakomodir kepentingan rakyat.

2. Hukum kodrat melengkapi aspek batin dan kejiwaan hukum positif

Hukum kodrat dan aturan hukum Pemilihan Umum harus saling mengisi untuk menciptakan keseimbangan sertakesejahteraan dalamkehidupan manusia. Karena aturan hukum Pemilihan Umum tidak dapat berjalan sendiri tanpa kehadiran hukum kodrat.

${ }^{14}$ Ibid, 
3. Hukum kodrat mengevaluasi keterbatasan hukum positif

Aturan hukum Pemilihan Umum tentu memiliki kelemahan-kelemahan yang harus dikoreksi dan dijadikan perubahan dalam perkembangan kehidupan bermasyarakat. Dalam hal inilah hukum kodrat harus hadir sebagai sarat kritik terhadap aturan hukum Pemilihan Umum guna membangun hukum yang lebih bermartabat.

Dari poin diatas, penulis menjelaskan bahwa semestinya keberadaan hukum kodrat dalam hukum positif untuk mewujudkan Pemilihan Umum Kepala Daerah Serentak yang berintegritas ialah hukum kodrat harus menjadi sarana pengaturan Undang-undang Pemilihan Umum Kepala, harus saling melengkapi antara Undang-undang Pemilihan Umum Kepala Daerah dan hukum kodrat ialah harus mampu menjadi sarana kebaikan dalam setiap konstelasi Pemilihan Umum serta kelemahan Undang-undang Pemilihan Umum Kepala Daerah harus dievaluasi sesuai dengan norma-norma hukum kodrat. Dengan kata lain, Pemilihan Umum Kepala Daerah Serentak yang berintegritas memerlukan hukum kodrat dan hukum positif untuk memperoleh validasi yang lebih fundamental dan final.

\section{Titik Temu Hukum Kodrat dan Hukum Positif dalam mewujudkan Pemilihan Umum yang berintegritas}

Sesungguhnya hakikat dari ajaran aliran hukum kodrat ini memandang bahwa alam harus dipelihara oleh manusia untuk mencapai tujuan. Sehubungan dengan perlunya kesadaran atas posisi manusia untuk menyesuaikan dengan kepentingan atau tatanan normatif yang terdapat dalam alam tersebut, maka tolok ukur hukum kodrat terhadap esensi hukum, terletak di mana apa yang dipandang sesuai dengan kepentingan alam adalah kebaikan, maka lakukanlah kebaikan dan bertindaklah secara adil dan apa yang jahat serta tidak adil harus dihindarkan. Hakikat ini merupakan aturan alam semesta yang diciptakan oleh Tuhan, dalam hukum abadinya, sehingga norma-norma dasar pada aliran hukum kodrat ini bersifat kekal, abadi, dan universal.

Tujuan hukum menurut hukum kodrat adalah harus mengandung nilai-nilai moralitas yakni untuk menuntun masyarakat menuju kebajikan dan menaati hukum karena merasa wajib secara moral sehingga dapat membuat masyarakat baik secara moral.

Melihat penjelasan di atas, dapat dikatakan bahwa hukum kodrat tidak lain adalah etika dan hukum kodrat dimanifestasikan dalam kewajiban moral. Hukum kodrat adalah dasar segala kewajiban manusia yang mendasari segala kewajiban. ${ }^{15}$ Diluar kaitan dengan hukum kodrat tidak ada kewajiban. Manusia mempergunakan hukum kodrat sebagai sarana untuk hidup dan bertindak sesuai dengan kodratnya sendiri. Hukum kodrat merupakan etika yang menempatkan manusia pusatnya, namun bukan dalam arti otonomi yang berlebihan, melainkan sebagai makhluk ciptaan. Jika dikatakan bahwa semua hukum harus berdasarkan hukum kodrat, maka hal ini menegaskan bahwa hukum harus menghormati martabat manusia. ${ }^{16}$

Secara garis besar, Thomas Aquinas yang merupakan pakar hukum menjelaskan bahwa teori hukum kodrat menjabarkan inti gagasan hukum kodrat yaitu: ${ }^{17}$

a. Kodrat manusia merupakan landasan aturan fundamental hukum kodrat, atau hukum kodrat diturunkan kepada manusia melalui rasionalnya sendiri.

b. Masing-masing kelompok aturan hukum kodrat disusun atas dasar putusan akal budi, dalam arti bahwa manusia menemukan hukum kodrat melalui kemampuan akal budinya dalam menyimpulkan intisari kodratnya sendiri.

c. Sebagai asas moral, aturan-aturan hukum kodrat menunjukkan perspektif tentang hukum yang lebih tinggi yang dapat dipergunakan untuk menilai atau mengevaluasi adat istiadat

\footnotetext{
${ }^{15}$ E Sumaryono, Op.Cit, hlm. 213.

${ }^{16}$ Frans Magnis Suseno. Etika Politik, Jakarta: Gramedia, hlm. 87.

${ }^{17}$ E Sumaryono, Op.Cit. hlm. 214.
} 
dan kebiasaan yang terdapat di dalam masyarakat. Hukum kodrat merupakan kriteria untuk merumuskan putusan-putusan moral.

Menurut kodratnya, manusia adalah makhluk rasional dan mengenali hukum kodrat melalui penalaran yang dipergunakan untuk menyimpulkan pengetahuan tentang kodrat manusia. Mengutip pendapat Thomas Aquinas, semua hukum dipromulgasikan melalui akal budi, sebab hanya melalui akal budi sajalah manusia dapat memahami hukum. Lebih lanjut, setiap hukum positif baru akan memiliki kodratnya sebagai hukum jika diturunkan dari hukum kodrat. Jika hukum positif dalam hal-hal tertentu, tidak mencerminkan hukum kodrat maka hukum ini sebenarnya bukan hukum melainkan hanya merupakan sesuatu yang mirip hukum. ${ }^{18}$ melanjutkan pendapat tersebut, hukum positif yang benar adalah yang tidak bertentangan dengan kebebasan dan cinta kemanusiaan. Hukum yang benar memungkinkan terselenggaranya kebebasan dan cinta, sebab kebebasan tidak mungkin terjadi jika tanpa cinta pada sesama (makna kebaikan). Cinta kepada sesama juga tidak mungkin tercipta tanpa keadilan, dan keadilan tidak mungkin terselenggara tanpa keberlakukan hukum yang legitimasi. Jika hukum disusun demi kebaikan umum, maka peraturan macam apa saja harus juga diarahkan demi kebaikan umum. ${ }^{19}$

Lebih lanjut, hukum positif yang adil memiliki daya ikat melalui hati nurani. Karena pembentukan hukum yang adil haruslah menjadi moral sebagai tolok ukur. Moral bangsa harus menjadikan asas-asas hukum dan asas hukum tercermin dalam kaidah atau norma hukum. Menurut A. Gunawan Setiradja, titik potong antara hukum dan moral adalah hukum kodrat. Pada hukum kodrat itulah ditemukan dialektika antara hukum dan moral. Moral mencakup dan mengatur hidup manusia dalam segala seginya, baik sebagai makhluk pribadi maupun sebagai makhluk sosial, mengatur hidup manusia, baik batin maupun lahir manusia. Semua yang terlibat dalam hukum positif, harus selalu ingat pada hukum kodrat, karena hukum kodrat adalah segi etis hukum positif. ${ }^{20}$

Persinggungan antara hukum kodrat dan hukum positif harus mengarah kepada kebaikan dan keadilan. Dalam pelaksanaan Pemilihan Umum yang berintegritas titik temu hukum kodrat dan hukum positif harus terus terjalin dan erat. Undang-undang Pemilihan Umum yang dibuat oleh legislator harus mampu mensejahterakan rakyat bukan mencelakai rakyat. Rakyat sebagai manusia yang juga subjek hukum haru mampu menaati Undang-undang Pemilihan Umum agar suatu cita-cita Pemilihan Umum yang berintegritas dapat terwujud. Dalam mewujudkan keberlakukan dan ketaatan kepada aturan hukum Pemilihan Umum keberadaan hukum kodrat tidak dapat dilupakan atau terabaikan.

\section{Upaya Hukum Kodrat dan Hukum Positif dalam Mewujudkan Pemilihan Umum yang berintegritas}

Konsep berintegritas Pemilihan Umum lebih didefinisikan kepada kualitas dan mutu. Untuk mewujudkan hal tersebut, penulis memberikan kerangka atau konsep pemikiran penulis tentang upaya hukum kodrat dan hukum positif dalam mewujudkan Pemilihan Umum Kepala Daerah yang berintegritas. Terdapat 2 (dua) aspek penting yang digunakan sebagai sarana hukum kodrat dan hukum positif dalam mewujudkan Pemilihan Umum Kepala Daerah yang berintegritas yakni pertama, hukum. Makna hukum ini bukan hanya terletak pada Undangundang Pemilihan Umum Kepala Daerah tetapi Undang-undang Pemilihan Umum Kepala Daerah harus mampu mewujudkan tujuan hukum yakni kemanfaatan, kepastian, dan keadilan hukum. Mewujudkan hal tersebut dengan cara yakni setiap pembentukan peraturan yang

\footnotetext{
${ }^{18}$ Ibid., hlm.209-210

${ }^{19}$ Ibid., hlm.219

${ }^{20}$ Otong Rosadi. (2010). "Hukum Kodrat, Pancasila, dan Asas Hukum dalam Pembentukan Hukum di Indonesia". Jurnal Dinamika Hukum, 3(10), 277-284.
} 
berhubungan dengan Pemilihan Umum Kepala Daerah harus dijelmakan norma-norma hukum kodrat yakni kebaikan dan keadilan. Didalam faktor hukum ini harus mampu sebagai sarana melegitimasi kepentingan rakyat agar nilai-nilai luhur dari Pemilihan Umum dapat terlaksana dengan baik.

Aspek yang kedua ialah manusia. Keberadaan manusia memegang peranan penting dalam terwujudnya Pemilihan Umum Kepala Daerah yang berintegritas. Selain peranan penting, manusia juga sebagai faktor penghambat terwujudnya Pemilihan Umum yang berintegritas. Dengan kata lain, apabila manusia melakukan perbuatan atau tindakan yang menyimpang pada saat Pra-Pemilihan Umum, Pemungutan Suara, dan Pasca Pemilihan Umum tentu akan merusak momentum Pemilihan Umum yang berintegritas. Perbuatan manusia menjadi titik kritis dalam hal ini, sesungguhnya keberadaan suatu aturan yang baik harus didukung oleh perbuatan manusia yang baik. Dalam memahami aturan atau hukum positif manusia membutuhkan hukum kodrat agar mampu memahami hukum positif dengan baik. Apabila hukum kodrat atau akal budi digunakan dengan baik maka tentu manusia akan memahami hukum dengan baik.

\section{KESIMPULAN}

Berdasarkan penjelasan pada bagian pembahasan, maka kesimpulan yang diambil oleh penulis ialah penerapan hukum kodrat dan hukum positif dalam mewujudkan Pemilihan Umum yang berintegritas harus dilihat dari 2 (dua) aspek yakni aspek hukum dan aspek manusia. Kedua aspek ini harus membentuk satu kesatuan dan fungsi yang mengedepankan prinsip hukum kodrat dan akal budi agar mampu berjalan dan seiring dalam setiap konstelasi Pemilihan Umum. Saran yang diberikan oleh penulis ialah Saran yang diberikan dalam tulisan ini ialah titik persinggungan pokok antara hukum kodrat dan hukum positif yakni moral harus terus dimanifestasikan dalam kehidupan manusia terutama dalam setiap proses Pemilihan Umum.

\section{DAFTAR PUSTAKA}

\section{Buku}

E Sumaryono. (2002). Etika dan Hukum. Depok:Kanisius.

Frans Magnis Suseno. (2016). Etika Politik. Jakarta: Gramedia.

Moh.Kusnardi dan Harmaili Ibrahim. (1993). Pengantar Hukum Tata Negara. Jakarta:Sinar Bakti

Muhammad Erwin. (2012). Filsafat Hukum; Refleksi Kritis Terhadap Hukum. Jakarta: Raja Grafindo Persada.

Peter Mahmud Marzuki. (2005). Penelitian Hukum. Jakarta: Kencana.

\section{Jurnal}

Bambang Satriya. (2017). "Urgensi Integritas Penyelenggara Pemilihan Umum dalam Menegakkan Kedaulatan Rakyat”. Jurnal Etika dan Pemilu, 3(1):10-21.

Jeremia Alexander Wewo. Kotan Y. Stefanus. and Umbu Lili Pekuwali. (2018). Code Of Ethics Urgency In The Implementation Of General Election In Indonesia. Jurnal Dinamika Hukum, Faculty Of Law Universitas Jenderal Soedirman, 18 (2): 194-199.

Otong Rosadi. (2010). "Hukum Kodrat, Pancasila, dan Asas Hukum dalam Pembentukan 
Hukum di Indonesia”. Jurnal Dinamika Hukum, 3(10), 277-284.

\section{Internet}

www.wikipedia.com, Pemilihan Umum di Indonesia, diunduh pada Tanggal 29 Oktober 2019 Jam 19.30 Wita

https://news.detik.com/berita/d-4596501/ini-270-daerah-yang-gelar-pilkada-serentak-2020 diunduh pada Tanggal 29 Oktober Jam 20.25 Wita

https://beritagar.id/artikel/berita/masalah-dan-potensi-masalah-menjelang-pemilu-2019 diunduh pada tanggal 29 Oktober 2019 Jam 20.45 Wita 